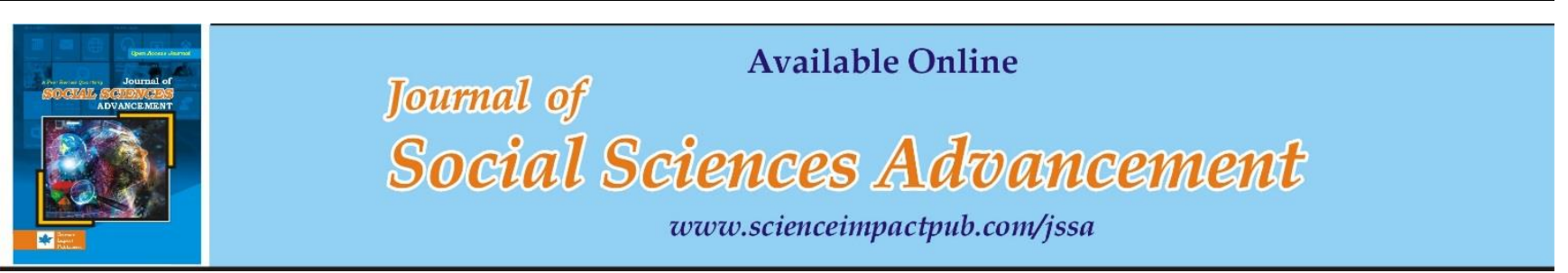

\title{
COVID-19 Pandemic: Assessment of its Impact and Insurability of Pandemic Risks in the Nigerian Insurance Business
}

Omotayo Johncally Abere ${ }^{1}$, Toyin Shafau Saka ${ }^{2}$

1Department of Actuarial Science \& Insurance, University of Lagos, Nigeria

2Department of Insurance, School of Management and Business Studies, Lagos State Polytechnic, Nigeria

\begin{abstract}
Coronavirus is a virus whose genome consists of a single strand of ribonucleic acid. The timing and the global environment (China) which COVID-19 originated from has made its spread faster than expected because China had 739 international air travel routes and 51 million people used to travel between China and other countries before the disease outbreak. Therefore, there is a need to investigate the impacts and the mortality rate of this deadly disease in order to consider its insurability. The specific objective of this research is to analytically examine factors affecting the insurability of pandemic risks in the Nigerian insurance business within specified time frame. Different methods/strategies of investigations were conceived to gather data/materials related to the study in order to have comprehensive knowledge on the subject matter. The two statistical tools used are descriptive and inferential. Kaplan Meier Model was used to carry out the hazard estimate based on the computation arrived at using Microsoft Excel package. This study analyzed 167,467 cases reported/observed within seventeen (17) months in Nigeria (Feb 2020-June 2021). The geographical location of this research is global. It is not limited to Nigeria alone but special attention was paid to cases in Nigeria to consider insurability of pandemic risks by the Nigerian insurers. 0.5 connotes equal chance of death and survival. As the value moves closer to 1 from 0.5 , the probability risk of death is becoming more certain and vice versa. It is clear from the analysis that as months passed by, the estimated figures began to increase showing that more deaths were being recorded. The lockdown and other safety measures adopted to fight COVID-19 disrupted economic recovery, affected financial markets/services and in turn increased insurance claims. The pandemic impacts on the global insurance markets have been largely affected as a result of weaker premium growth prospects, capital market volatility, asset risks and so on. In time of crisis, losses come as well as opportunities. This study suggested how identified negative impacts of COVID-19 could be minimized while strategizing to maximize the opportunities therein. It also showed analytically how high mortality risk poses threat to insurability of pandemic risks.
\end{abstract}

\begin{tabular}{l}
\hline Keywords: Deaths; Hazard estimate; Insurance; COVID-19; Censoring; Pandemic risk; Cases; Mortality \\
\hline${ }^{*}$ Corresponding Author: Omotayo Johncally Abere, Email: johncally68@yahoo.com \\
(C) The Author(s) 2021.
\end{tabular}

\section{INTRODUCTION}

COVID-19 global pandemic came as a shock to a large number of health system stakeholders, societies, economies and even governments of powerful countries. It is time to pull ourselves together and make some critical decisions to manage the immediate impacts of the pandemic and its consequences by valuing what is absolutely important. The decisions to make should be able to position the economies for better years to come in the sustainable and equitable world. WHO (2020) describes coronavirus as a virus whose genome contains a single strand of ribonucleic acid. WHOChina Study (2021) discovered that many people had lost their lives in Wuhan as a result of the coronavirus disease before it was officially discovered or reported and gained global attention. The initial deaths before the discovery were counted as normal/common ailment until large number of people died of the presumed and purported common ailment more than expected. Therefore, there is need to investigate and assess the impacts of this disease on the general public and the economy .In time of crisis, losses come as well as opportunities. To have a full control of the situation, we take steps that attempt to minimize the losses associated with pandemic risks while maximizing the opportunities. When the number of cases recorded went higher all over the world, travel ban, mass quarantine and lockdown were adopted (Abere, 2020). These measures provided safety at that time but also negatively impacted on the stability of various businesses, both domestic and international. Many businesses (such as tourism, transportation, restaurants, hospitality/hotel, rental, schools, event centre, entertainment, optional personal services, etc.) suffered a lot. In order to obey the safety measures put in place, businesses combine online based platform or virtual service provisions with their physical or initial platform to allow their businesses function without interruption. The pandemic has opened peoples' eyes to remote working as digital platforms have become more useful (Gray and Schlemmer, 2020). 
Insurance cover is typically about protection. Characteristics of insurance business make it a complex business due to different and multiple processes it entails in selling new policies, pricing the new product, administering existing policies, addressing customers' enquiries, renewing policies, maintaining good relationship among insurance external networks ( like brokers, agents and other intermediaries) and processing claims. COVID-19 outcomes on insurers are overwhelming. It has challenged the operations of insurers and it is of no surprise that operations of insurers have been seriously affected and disrupted in a period like this. A lot of customers are contacting their insurers for claims or clarifications on whether their covers are applicable to some certain circumstances happening around them. Claims in some insurance covers (like critical illnesses, business interruption and other health covers) had been drastically increased while some claims (like motor insurance) dropped more than 20\% during the lockdown and movement restriction period (Hay, 2020). It is not possible to forget quickly the trauma and experiences witnessed, especially the human losses. Apart from direct impacts of COVID-19 on human health, there have been significant global impacts on commerce, business and economy (World Economic Forum, 2020). The pandemic has made it unavoidable to urgently respond to some trends especially digitization and climate change. Climate change is linked to physical and liability risks and thus, indirectly affects investment and business operations.

This study will provide answers to questions such as: What are the best lines of actions as companies resume for work in the face of uncertain future? What is next as COVID-19 crisis has wrenched the trajectory growth of energy demand? What else needs to change as pandemic has changed our lives, work and situations? What is the mortality estimate of COVID-19? What can be done to insure pandemic risks? This paper will assess the impact of COVID-19 and also identify elements in insurability of pandemic risks. Therefore, the specific objective of this research, which must be attained at the end, is to analytically examine factors affecting the insurability of pandemic risks in the Nigerian insurance business within specified time frame. The geographical location of this research is global (worldwide). It is not limited to Nigeria, although concise attention will be paid to COVID-19 cases and the mortality experiences in Nigeria. This study will provide a basis for health policy making which will ultimately lead to a decrease in unwarranted deaths and overall development in the quality of life. Through Infection Prevention and Control (IPC), evidence shows that measures have been effective in reducing number of cases (WHO, 2021).

\section{LITERATURE REVIEW}

Bouey (2020) observed that the virus that causes COVID-19 is SARS-COV-2 and it is a member family of coronaviruses. According to WHO (2020), other members are SARS-COV and MERS-COV whose strain fatality rates are about 9.6\% and $34.4 \%$ respectively. Bouey confirmed that the timing and the global environment (China) which COVID-19 originated from had made its spread faster because China had 739 international air travel routes and 51 million people used to travel between China and other countries per year before the disease outbreak (Aslam et al. 2020). Also, Wuhan (the epicenter of the outbreak), is referred to as the Chicago of China because it is the most important transportation hub in the Central China with about 30000 people flying out of the city daily while many more travel through the three city railway stations to various regions. Therefore, it was very easy for the outbreak to spread quickly to the nooks and crannies of the world. Another factor that aided the spread was that January 2020, was Chinese Lunar New Year. That time contributes to more than three billion trips usually recorded yearly in China (Bouey, 2020). Lockdown was adopted at some points to curb the spread of the disease. During the time, there was lower level of pollutants due to no or low industrial production of some goods or rendering of some services. During movement restriction period, insurers who had advanced digital underwriting, administrative and claim processes functioned better than those who relied on crude technology and struggled more to stay relevant in the industry. The level of capabilities will make those insurers to lose their customers to those who are more technological and digitally advanced. Rossouw (2020) raised concern that too much claims made by the insured have made the solvency and the financial conditions of insurers to be nothing to write home about. He stated that Italy's insurance regulators raised the capital base of insurers by $€ 500 \mathrm{~m}$ following the solvency falling below the minimum requirement. Insurers need to work hand in hand with the regulators to ensure regulations are contributing to the industry progress and not hindering the untapped opportunities that arise with this period.

Hay (2020) found out that the pandemic made the workforce of the badly affected countries to reduce by $30 \%$ to $40 \%$. She also observed that remote working has brought more fraud or cyber risks. The pandemic is making all businesses to improve on their digital transformation and transmission priorities. This will in turn promote systemic vulnerability to cyber-attacks. Cyber IT and forensic teams are to work round the clock, monitor and scan any unusual activities to ensure services are not disrupted or interrupted by hackers as this will open way for cyber insurance soonest. Laura Hay, the global head of insurance at KPMG International, identified integrity and empathy to customers as the most important principles in the pandemic time. These principles will increase insurers' communication with their customers and show high degree of proactive customer-driven support. Rebate can be given to the insured on some types of insurance covers as a result of no or less activities that could give rise to certain claims at some point. This action is necessary so that some customers will not begin to question their insurance holdings and lead them to ask themselves questions that may render importance of insurance as optionally useless. Due to COVID-19, people 
purchase more of life/health insurance covers that can get them access to healthcare providers or services than insurance covers that give only payouts. Insurers must rethink to design their products to adjust or respond to their customers' needs to suit various circumstances/situations of this season. In order not to materially deteriorate the operational performance, the reinsurance should come in to cushion the business losses in some situations such as event cancellation, business interruption and other consequential losses. Insurance companies excluded pandemic risks from their policy payouts because they have learnt from previous SARS epidemics. This exclusion will be a bit difficult in some health policies because they include medical services and testing.

S\&P Global (2020) highlighted some common risks associated with pandemic situations. These include: investment performance risk, country risk, exposure to high-risk assets, intense competitive environment, government and regulatory policy risk, muted market growth prospects, weak technical results, foreign exchange impacts, litigation risk and exposure to natural catastrophes. As the pandemic spreads, the insurance attention has been drawn to unnoticed protection gap in insured and noninsured risks (Birriteri, 2020). The uninsured losses are growing geometrically than the insured losses. Ozili (2020), in his study, affirmed that the fragile healthcare systems of African countries made COVID-19 impacts to be felt greatly more than it should have been. It became a national crisis when the available healthcare facilities could not accommodate or cater for the people hit by the virus. Developed countries provided stimulus packages, social welfare packages and other relief materials for their citizens to cushion the effects and the impacts of the pandemic. Underdeveloped and some developing countries made their citizens go through tough time by their inability to give them adequate provision.

According to World Economic Forum (2020), the competences of our leaders at various levels and the qualities of their governance have been exposed by the COVID-19 pandemic. When the leaders/governments fail to deliver, rescue, assist or protect their people from the devastating effects of diseases, they lose not only the credibility and competence but also the legitimacy of the offices or positions they hold. The government should be able to take care of the needs of the citizens especially at the time it is impossible for them to take care of themselves due to government directives or measures adopted to curb any unfortunate events. Educational institutions were affected and their academic calendars were also disrupted as a result of the safety measures put in place (Marsh, 2020). Students who wanted to travel abroad to further their study could not do so. Local and international conferences were cancelled. These adverse impacts of COVID-19 widened the learning and teaching gaps which resulted into loss of man power or capable hands in the education sector. There was also a budget cut in the educational institutions at both private and public schools due to reduction in the revenues. Ozili pointed out that between January and April (2020), the Nigerian Stock Exchange witnessed huge loss in stock returns and recorded higher stock returns volatility.

Andrew (2020) advised all insurers to manage the COVID-19 negative impacts and position themselves to exploit the opportunities that accompany the threats. He stated further that some areas insurers should focus on are claim management, financial management, business management, distribution management, customer management, proposition management and organizational support services. These areas constitute reference or key themes in the operations of insurance business. New capabilities are required from businesses emerging from the pandemic crisis in order to face the environmental and digital future (McKinsey, 2021). In other words, new set of skills (such as digital capabilities, advanced cognitive, crisis management, emotional or social skills) are needed for business to flourish adequately. World Economic Forum (2020) confirmed that the losses incurred by insurers due to pandemic crisis have become so large that they cast a doubt on their solvency. The claims paid within a month were confirmed to be over ten times of claims witnessed in a whole year. If such claims continue to rock insurers, their reserves, surpluses and capital base will likely be wiped out (Pandemic Report, 2020). In lieu of this, pandemic losses are typically and technically excluded from insurance policies. COVID-19 plunged all nations into disarray. Much attention has always been on the health impact or matter. As a matter of fact, mental depression, nationalist behavior, domestic violence/conflicts, rape cases and other socio-psychological effects were largely reported and documented during lockdown and movement restriction measures.

The new daily COVID-19 cases and deaths have been reducing globally, although some regions are still showing a sustained upward trend in the number of new cases and deaths. Higher mortality rates are expected in such regions and will affect life insurers (S\&P Global, 2021). Digitization of insurance sales channels to enhance uninterrupted network should be considered as a better marketing alternative to face-to-face approach where COVID-19 cases are still not reducing drastically (Ajibo, 2020). WHO, in conjunction with other national health bodies, researchers and institutions, periodically assesses if variants of COVID-19 result in changes in transmissibility, severity and clinical presentation by health authorities. Insurance policy should create a room for emergency response plan that will fast track claim settlement for policyholders in time like this. In China, health policy coverage has been extended to cover COVID-19 related death (Hay, 2021). Hay stated that healthcare costs are mostly covered by the public health system in Italy as government provides affordable health insurance for its citizens to avoid unnecessary deaths. Systems have been designed in some countries to identify potential variants and assess them in relation to the risk posed to the people. The economic slowdown is really affecting and shrinking the activities of insurance business in real terms. 
COVID-19 has negatively contributed to financial crises Nigeria was going through prior to the pandemic period. The pandemic has caused hyperinflation as prices of items have skyrocketed beyond imagination (Ozili, 2020).

In a study carried out by World Food Program (2020), the pandemic has brought job destruction as a result of folding up of businesses. The high unemployment rate and minimum wage tussle in Nigeria have made some employers to prefer casual/temporary workers with less pay as compared to permanent full time workers. Invariably, this has led to income inequalities among the workers in Nigeria. On the part of business owners who run their business on loans, the pandemic has seriously affected the loan repayment arrangement. Inability to service their loans timely will in turn affect the creditors' earning capacity and stability. Therefore, the banks or creditors will be reluctant to give out loans. They will only be willing to provide loans at high interest rates which will definitely increase the cost of production of goods and services. Due to movement restriction at some time, demand for fuel (aviation and automobile) reduced drastically. This made oil prices to fall and affected the net revenues and foreign reserves of some oil producing countries (World Bank Group, 2020). Furthermore, some exporting and importing businesses could not operate properly at that period due to closure of borders. The budgets of the oil and import dependent countries (like Nigeria) were absolutely and negatively affected. Capital markets were also not left out in the hit as most market indices were not that satisfactory to the investors. At that time, most investors pulled out their investment since there was no much productive activities they could fall back to cater for their immediate needs. The effects of COVID-19 are gradually fading out in most countries. It is important to create a recovery pathway for organizations to reposition themselves for effective reinstatement (PWC, 2020). The contractual coverage of mortality, health and health related liability risks have made pandemic a significant matter directly affecting insurance organizations (Thorburn, Gonulal, Remizova and Shindo, 2020). The pandemic has impacted on insurers in three main aspects, which include operational challenges, asset value/liquidity and insurance obligations to its customers.

\section{METHODOLOGY}

\section{Methods of Data Collection}

Different strategies and methods of investigations were used to gather data on the study in order to have adequate knowledge on the subject matter. Visits were made to experts, hospitals, friends and family members in the relevant organizations for personal interviews and corporate observations. The major secondary data were obtained from the internet, forums, paper presentations, newspapers, periodic reports, journals and other publications of health and health related organizations. Inconsistencies were observed from different sources of available data on the number of deaths and cases arising from COVID-19 (Shafiq et al. 2020; Shafiq et al. 2018). These inconsistencies occurred due to late or unreported case incidences (Phuc et al. 2020). Sometimes, some cases were double counted or reported more than once. Nevertheless, the statistical tools employed in the course of this research have been suitably chosen to maximize the consistencies and minimize the inconsistencies to the barest minimum. Most data are generally drawn from the reports of World Health Organization (WHO), Centres for Disease and Control (CDC) and other approved data collation centers/ organizations/bureau. As a matter of fact, the reliability of the estimates from the data used depends upon the overall quality of the sampling frames (Parveen et al. 2021; Parveen \& Tran, 2020). The samples here comprise the number of people that were actually tested for COVID-19. Generally, the larger the sample frames, the better the validity and quality of the result/estimate. As at $28^{\text {th }}$ June, 2021, the Nigeria Centre for Disease Control (NCDC) made it known in their daily report that out of 2266591 people tested, a total number of 167467 people had been infected so far as shown in the figure below. This research shall carry out analysis on 167467 cases reported/observed within seventeen (17) months (i.e, Feb 2020 to June 2021). This number represents cases reported at the time the data was retrieved.

\section{COVID-19 Cases in Nigeria}

This figure may not be the same later due to unreported cases which might be added to the earlier reported figure as soon as the figure uncovered. As reported by the Nigeria Centre for Disease Control (NCDC) and confirmed by the World Health Organization (WHO) on May 9, 2021 (Week 18), the Nigerian new confirmed cases reduced from 462 in previous week to 238 in 16 states and the Federal Capital Territory (FCT). Also, the number of people discharged rose to 936 from 435 in the 17th Week (WHO, 2021). It was stated by WHO that as at May 9, 2021 in Nigeria, 2065 deaths had been recorded out of 165419 cases with CFR (case fatality rate) of $1.2 \%$. Globally, out of 157289118 cases, 3277272 people died so far with CFR of $2.1 \%$. 


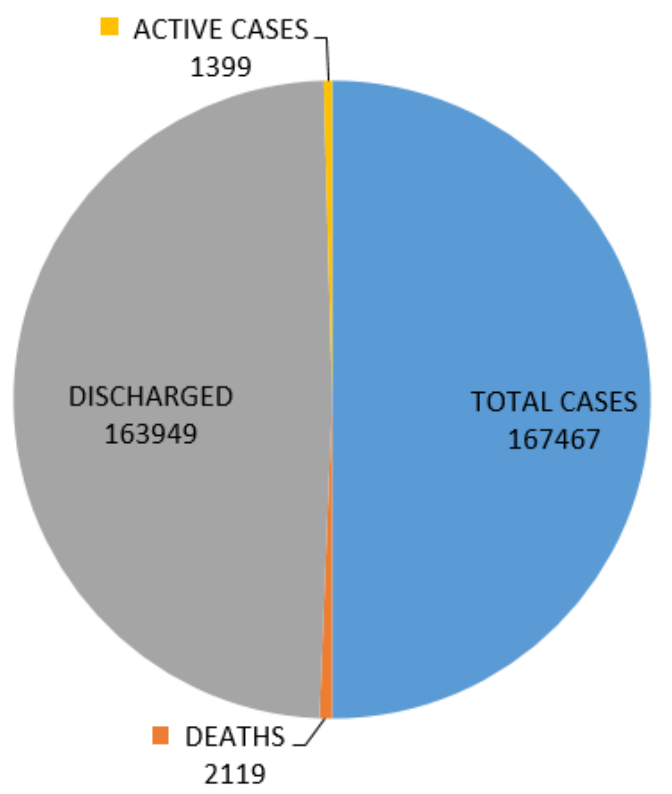

Source: worldometer (https://www.worldometers.info/coronavirus/country/nigeria/). Accessed/updated on June 28, 2021 at 00:58 GMT

Table 1: Cumulative Number of Cases, Deaths and Discharged

\begin{tabular}{|c|c|c|c|c|}
\hline Year & Month & Cases Reported & Discharged & Deaths Reported \\
\hline \multirow{11}{*}{ 疋 } & February & 1 & 0 & 0 \\
\hline & March & 135 & 8 & 2 \\
\hline & April & 1932 & 319 & 58 \\
\hline & May & 10162 & 3007 & 287 \\
\hline & June & 26484 & 10536 & 590 \\
\hline & July & 43151 & 19565 & 879 \\
\hline & August & 54008 & 41638 & 1013 \\
\hline & September & 58848 & 50358 & 1112 \\
\hline & October & 62853 & 58675 & 1144 \\
\hline & November & 67557 & 63282 & 1173 \\
\hline & December & 86576 & 72682 & 1289 \\
\hline \multirow{6}{*}{ ָָ } & January & 131242 & 104989 & 1586 \\
\hline & February & 155657 & 133768 & 1907 \\
\hline & March & 162891 & 151648 & 2057 \\
\hline & April & 165110 & 155101 & 2063 \\
\hline & May & 166518 & 158784 & 2099 \\
\hline & June & 167467 & 163949 & 2119 \\
\hline
\end{tabular}

\section{Statistical Tools}

Censoring mechanisms play vital role in the inferences of this research. Data are censored provided that the exact values observed are not known or accurate but the information concerning each observed value as it connects to one another is guaranteed (Abere, 2020). Right censoring mechanism is used when the cases being investigated or studied are still alive when the study ended. Non-informative censoring gives low information about the exact lifetimes of the observed cases (Aslam et al. 2021). Type 1 censoring is when the censoring time or duration is known in advance. When the actuarial investigation of events falls within certain observational interval of time, it is known as Interval Censoring Shafiq et al. 2019). Assumption of Type 1, right, non-informative and interval censoring will be employed in this research. The assumption of interval censoring is expedient because the design observed events of interest within certain interval period of time. In this paper, the investigation of cases was carried out from the month of February, 2020 to the month of June, 2021. Descriptive and inferential statistics were used in this paper. The descriptive statistics is concerned majorly with summary calculations or graphical displays of data to derive decisions (Mojekwu, 2012). It must be noted that the displays or summary calculations describe the general characteristics of the data without going deeper into those characteristics (Shafiq et al. 2020). The inferential statistics is how inferences are obtained from numerical data. It depicts analysis/interpretation of the characteristics of data to arrive at appropriate decisions. The Kaplan Meier (KM) or Product Limit (PL) Model is a non-parametric approach used in 
calculating the estimate of the distribution function. It will show the future lifetime random variables in the data distribution. It will be used to analyze the hazard rate/estimate of data displayed in Table 1 using Microsoft Excel Package for the computation. This estimate ranges from 0 to 1 . Value 0 means no chance of death at all while value 1 means a $100 \%$ risk of death in the observed live.

\section{Kaplan Meier estimate formula/notations}

\section{Kaplan Meier estimate $\left(\mathrm{F}_{\mathrm{KM}}(\mathrm{y})\right)$}

Estimate/rate that an infected person dies at time $y$

Month of observation

Month/time death observed

Number of deaths at month $m_{y}$

Number of infected person exposed to death riskat $m_{y}$

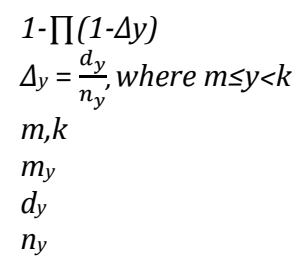

\section{ANALYSIS AND INTERPRETATION OF DATA}

\section{Analysis}

In Kaplan Meier Model, 0.5 connotes equal chance of death and survival. This model was chosen to analyse the data because it is a non-parametric approach whose estimate assumption is based on non-informative censoring. As the value moves closer to 1 from 0.5 , the probability risk of death is becoming more certain and vice versa. Table 2 is the result of Kaplan Meier of the data displayed in Table 1.

Table 2: Computation of the Estimate of Future Lifetime Distribution Function

\begin{tabular}{crrrrrrr}
\hline $\mathrm{m}_{\mathrm{y}}$ & \multicolumn{1}{c}{$\mathrm{d}_{\mathrm{y}}$} & \multicolumn{1}{c}{$\mathrm{n}_{\mathrm{y}}$} & \multicolumn{1}{c}{$\Delta_{\mathrm{y}}$} & \multicolumn{1}{c}{$1-\Delta \mathrm{y}$} & \multicolumn{1}{c}{$\Pi(1-\Delta \mathrm{y})$} & $1-\Pi(1-\Delta \mathrm{y})$ & $\mathrm{m} \leq \mathrm{y}<\mathrm{k}$ \\
\hline 1 & 0 & 1 & 0 & 1 & 1 & 0 & $1 \leq \mathrm{y}<2$ \\
2 & 2 & 125 & 0.016 & 0.984 & 0.984 & 0.016 & $2 \leq \mathrm{y}<3$ \\
3 & 56 & 1555 & 0.0360128617363344 & 0.963987 & 0.948563 & 0.051436656 & $3 \leq \mathrm{y}<4$ \\
4 & 229 & 6868 & 0.0333430401863716 & 0.966657 & 0.916935 & 0.083064642 & $4 \leq \mathrm{y}<5$ \\
5 & 303 & 15358 & 0.0197291313973174 & 0.980271 & 0.898845 & 0.10115498 & $5 \leq \mathrm{y}<6$ \\
6 & 289 & 22707 & 0.0127273527986964 & 0.987273 & 0.887405 & 0.112594897 & $6 \leq \mathrm{y}<7$ \\
7 & 134 & 11357 & 0.0117988905520824 & 0.988201 & 0.876935 & 0.123065293 & $7 \leq \mathrm{y}<8$ \\
8 & 99 & 7378 & 0.0134182705340201 & 0.986582 & 0.865168 & 0.13483224 & $8 \leq \mathrm{y}<9$ \\
9 & 32 & 3034 & 0.010547132498352 & 0.989453 & 0.856043 & 0.143957279 & $9 \leq \mathrm{y}<10$ \\
10 & 29 & 3102 & 0.00934880722114765 & 0.990651 & 0.84804 & 0.151960258 & $10 \leq \mathrm{y}<11$ \\
11 & 116 & 12605 & 0.00920269734232447 & 0.990797 & 0.840235 & 0.159764511 & $11 \leq \mathrm{y}<12$ \\
12 & 297 & 24667 & 0.012040377832732 & 0.98796 & 0.830119 & 0.169881264 & $12 \leq \mathrm{y}<13$ \\
13 & 321 & 19982 & 0.016064458012211 & 0.983936 & 0.816783 & 0.183216671 & $13 \leq \mathrm{y}<14$ \\
14 & 150 & 9186 & 0.0163291966035271 & 0.983671 & 0.803446 & 0.196554087 & $14 \leq \mathrm{y}<15$ \\
15 & 6 & 7946 & 0.000755096904102693 & 0.999245 & 0.802839 & 0.197160766 & $15 \leq \mathrm{y}<16$ \\
16 & 36 & 5638 & 0.00638524299396949 & 0.993615 & 0.797713 & 0.20228709 & $16 \leq \mathrm{y}<17$ \\
17 & 20 & 1399 & 0.0142959256611866 & 0.985704 & 0.786309 & 0.213691134 & $\mathrm{~m} \geq 17$ \\
\hline
\end{tabular}

Source: author's calculation using data in Table 1

\section{Interpretation}

In the analysis in Table 2, we observed a sample of 167467 affected people out of a population of 2266591 people tested for their COVID-19 statuses in Nigeria. The hazard estimate and the range of time it applies have been shown for better understanding. Also, the value of $y$ which $\Delta_{y}$ applies has been stated in the last column of the table. The more the number of $m_{y}$ the more the estimate tends to one. If there are no infected persons remaining to be censored among the observed lives when the investigation ended or if this research was designed to continue until the last live either dies or survives, the last value of the estimate will be one (1) which means survival at that time. The analysis shows that at the initial month of the investigation, the estimate is zero $(0)$ which signifies that no live was lost due to the virus in the first month of investigation. This does not mean that the virus did not kill the infected persons in that month. It means that no death was reported among the cases of infected persons investigated by this research work in that month. It is clear from the analysis that as months pass by, the estimate figure begins to increase showing that more deaths will be recorded if appropriate medications are not administered. In other words, there are chances of surviving the deadly disease at the earlier time of the infection if the infected persons take adequate medical care. Alternatively, as shown in the table, the more the virus lives in the host, the higher the probability of death and lower the chance of recovery from the disease.

In practical application, using the result obtained in this research to forecast any future outbreak of this virus will help the insurers in pricing or charging adequate and suitable premium for this product should they consider its insurability. The death rate computed will guide the insurers and the insurance regulatory authorities in making crucial decisions on appropriate capital base required, reserving and other financial management decisions. For instance, $m_{2}$ row in Table 2 shows a value of 0.016 . This indicates that out of the people infected in the first two 
months, sixteen (16) out of a thousand (1000) insured lives are expected to die from the disease. Therefore, insurers will charge premiums that can make them have adequate claim reserves for this huge loss while the regulatory authorities will ensure the insurers have adequate capital base to face the claim demand. However, this forecast will be valid if responses that are aimed at mitigating or preventing exposure to the pandemic risk factors and uninterrupted access to health care are not effectively employed. Health is wealth and life becomes short when its quality is poor.

\section{SUMMARY, CONCLUSION AND RECOMMENDATION}

This period has witnessed a lot of staff working from home. This has brought increase in the use of technology to communicate or network people together in different locations. Old technology replacement should be given high priority to improve/advance digital services and give adequate level of operational resilience. Some markets/services have been affected globally as a result of low economic activities. These low economic activities have negatively and adversely impacted on various investment incomes. Investment portfolios should be reviewed to know how to respond to similar scenario in the future. This research has used Kaplan Meier Model to measure the mortality rate among people affected by COVID-19 in Nigeria. There are many factors that determine the future lifetime of sufferers. Age is the most important factor in this but not the sole determinant. Underwriting discipline needs to be exercised and a clear view of risks involved as a result of loss occurrence should be maintained in order to consider or provide cover for pandemic risks. In order to incorporate pandemic risks into disaster insurance, the premium cover must be very expensive than any form of insurance. The high premium will provide potential to take care of devastating high losses that may arise. The resultant effect of the huge premium is that only the rich individuals or big business organizations can afford it. Many entities, small and medium scale business will not key into the arrangement. This will have negative impact on insurers as total premium realized from the few people insured cannot provide adequate reserve when catastrophic losses actually occur because insurance needs a large number of insured for the purpose of risk pooling which will enable insurers withstand numerous claims.

The unfortunate future events will not exactly be like the past. Therefore, we must think beyond the current devastating tolls cast by COVID-19 pandemic in order to develop formidable systems that can give effective responses to any form of pandemic disaster at full range/capacity when it evolves. The most important thing in the postpandemic period is the need for business to learn how to thrive (Gasc, 2020). Small scale businesses are more financially fragile when the market/service demand is low or down. This research recommends that stakeholders and governments at various levels should prompt to salvage the situations of these businesses by initiating emergency funding programs that can prevent bankruptcy and make them stay afloat in the face of low or no market/service demand. Governments should encourage businesses to continue functioning or operating by lowering interest rates to make borrowing easier or deferring/waving some fees/taxes in order to address business financial and operation challenges (World Bank Group, 2020).

In order to curb the cyber risks accompanying remote working, clear guidelines should be given to employees on remote connectivity procedures and best practices on matters relating to file sharing and data distribution to prevent hacking attempts which can allow criminals to have access to customers' data, financial information or other confidential details. In order to reduce the frequent contacts of the insured with the insurers on unnecessary enquiries, this research agrees with Chidozie and Abioye (2020) that not only insurance industry but also every business organization should update their online channels to give clear and unambiguous responses to the frequently asked questions (FAQs) section because the pillars or principles that build good relationship between customers and business organizations are resolutions, integrity, expectation, time/effort, empathy and professionalism. Prices of commodities in Nigeria have gone beyond imagination. This research recommends that the Nigerian economic system should be reformed to make rooms for demand and supply shocks, economic diversification to reduce over reliance on oil revenues and for preparedness for any unfortunate events like disease outbreak. Insurers are already exhausting their reserves as increase in claims has moved them closer to the regulatory minimum capital required (Hartwig, 2020). There is need for insurers to formulate new models for financial performance as existing models, toolsets and scenario analysis may not appropriately conform to current situations.

Also, the actuarial analysis needs to be revised to reflect capital adequacy as a result the pandemic impacts on insurance business. Some claims in some types of insurance covers were huge due to COVID-19 impacts while some claims reduced in other types of covers. In order to encourage customers and promote business interaction, this research recommends that some percentage of the premiums should be given off by the insurers on some types of insurance covers that have generated no or low claims so far. This will contribute to positive customer behavior in relation to their perceptions of risks. As there should be reduction in premium due to low probability of claims, there should also be a proportionate increase in the premiums of some insurance products (like health insurance, cyberrisk insurance and business interruption) which have generated high probability of claims. Insurance should also review their policy wordings to reflect new changes and challenges arising from the pandemic potential risks. 
The underwriting and pricing manual should be updated to incorporate updated rules where necessary (PWC, 2021). The changes made should be communicated to the customers in clear terms to avoid misrepresentation or misconception. Year 2020 was a very difficult year for most insurance companies and their intermediaries, but financial indicators showing in this year 2021 raise hope that business operators will navigate through the difficulty without or with low impact on their qualities. Investment in digital economy and technology will play a crucial role in mitigating the adverse effects and impacts of the pandemic. Through e-commerce or online marketing app, buyers and sellers can get what they want at any particular time. At this point, it is advisable that business owners should divert or allocate their resources from non-critical areas to those areas of businesses mostly under intense operational pressure. Finally, we believe that there is considerable room for further research on this work. The data used have been censored. Lives observed were still alive at the time this research ended. Although appropriate censoring methods were used but it will be better to have a complete set of data by following up the observed lives till the outcome of the last live ascertained. Therefore, further work will be certainly warranted on this study area. However, this study has paved way for future research on insurability of pandemic risks and provided basic knowledge on the impact or assessment of the deadly disease, COVID-19.

\section{REFERENCES}

Abere, O. J. (2020). Survival Analysis of the Novel Coronavirus (2019-nCov) Using Nelson Aalen estimate. International Journal of Finance, Accounting and Corporation,1(1):17-24

Ajibo, H. (2020). Effects of COVID-19 on Nigerian Socio-Economic Well Being and the Role of Nigerian Socio Workers in the War against COVID-19. Social Work in Public Health,35(7):511 - 522 .

Andrews,M. (2020).Impacts of COVID19 on Insurance Businesses. Altus, England.

Aslam, S., Akram, H., \& Parveen, K. (2020). Cultural Differences and Problems: A case of International Students Studying in a Normal University in North China. Journal of Social Sciences Advancement, 1(01), 08-12.

Aslam, S., Saleem, A., Akram, H., Parveen, K., \& Hali, A. U. (2021). The challenges of teaching and learning in the COVID19 pandemic: The readiness of Pakistan. Academia Letters, 2.

Birritteri, l. (2020). How Has COVID-19 Impacted on Insurance. July23,2020. International Hospitality Media, UK.

Bouey, J. (2020).Assessment of COVID-19's Impacts on Small and Medium Size Enterprises Rand Corporation, Santamonica. March 10,2020

Chidozie, N. and Abioye, W. (2020) A Customer-First Approach during Unprecedented Times. Kpmg, Nigeria. A Customer-First Approach During Unprecedented Times (assets.kpmg)

Gasc, J (2020). COVID-19: Six Post-Pandemic Priorities Facing Insurers. Accenture Insurance Blog, 22 june, 2020.

Gray,J. and Schlemmer, l. (2020) The Impacts Of Covid-19 On Digitilisation in the Insurance Sector. May 29, 2020. The impact of COVID-19 on digitisation in the insurance sector insub-Saharan Africa - Cenfri

Hartwig, P.R.(2020) COVID-19: The Insurability of Pandemic Risks and Market Implications for Insurance Industry. Federal advisory committee on insurance, September 2020, University of South Carolina.

Hay, L.J. (2020). COVID-19: Insurance Operation Challenges. KPMG International,New York.

Hay, L.J. (2021). COVID-19: The Global Insurance Responses. KPMG Global,New York.

Marsh. (2020).COVID-19: Credit Risk Insurance Implications. March 2020. Marsh JLT Specialty,London

McKinsey (2021). Coronavirus' Business Impacts: Evolving Perspective. May 5, 2021. McKinsey \& Company, NewYork. Coronavirus' business impact: Evolving perspective | McKinsey

Mojekwu, J.N.(2012): Business Statistics with Solved Examples (3rd Ed. Chapter 1, Pg 1). Easy Prints Publication, Lagos, Nigeria

Ozili, P. K. (2020). COVID-19 Pandemic and Economic Crisis: the Nigerian Experience and Structural Causes. MPRA Paper no: 103131 https://mpra.ub.uni-muenchen.de/103131/

Pandemic Report (2020). COVID-19: Evolving Insurance and Risk Management Implications. Marsh \& mclennan companies, New York. March 2020. COVID-19: Evolving Insurance and Risk Management Implications (marsh.com)

Parveen, K., \& Tran, P. Q. B. (2020). Practical problems for low quality education and steps needed for investment in public schools of Pakistan. Journal of Social Sciences Advancement, 1(01), 01-07.

Parveen, K., Phuc, T. Q. B., Shafiq, M., \& Wei, T. X. (2021). Identifying the administrative challenges encountered by the principals in low-performing public secondary schools of Faisalabad District, Pakistan. International Journal of Humanities and Innovation (IJHI), 4(1), 5-16.

Phuc, T. Q. B., Nguyen, L. D., Parveen, K., \& Wang, M. (2020). Developing a theoretical model to examine factors affecting school leadership effectiveness. Journal of Social Sciences Advancement, 1(01), 16-29.

PwC (2020). Key Financial Reporting Implications of COVID-19 on Organisations in Nigeria. Pwc ltd, Nigeria. Key financial reporting implications of COVID-19 in Nigeria (pwc.com)

PwC (2021). COVID-19: Impact to Business. PwC Global, UK. COVID-19: Impacts on business PwC

Rossouw, R. (2020). Using the Hindsight to Gain Foresight. Institute and Faculty of Actuaries (ifoa), UK. October 28.Covid-19: Using hindsight to gain foresight (actuaries.org.uk) 
S \&P Global (2020). Insurance Industry and Country Risk Assessment Updates, 14 Nov. America, New York.https://www.spglobal.com/ratings/en/research/articles/201117-insurance-industry-and-country-riskassessment-update-november-2020-11739874

S \&P Global (2021). How COVID19 Has Changed Insurance. 14 December. America https://www.spglobal.com/en/research-insights/featured/how-covid-19-has-changed-insurance

Shafiq, M., Zhang, Q., \& Akbar, M. A. (2019, December). Software requirements engineering maturity model (SREMM) in offshore software development outsourcing. In 2019 International Conference on Frontiers of Information Technology (FIT) (pp. 101-1013). IEEE.

Shafiq, M., Zhang, Q., Akbar, M. A., Alsanad, A., \& Mahmood, S. (2020). Factors influencing the requirements engineering process in offshore software development outsourcing environments. IET Software, 14(6), 623-637.

Shafiq, M., Zhang, Q., Akbar, M. A., Kamal, T., Mehmood, F., \& Riaz, M. T. (2020). Towards successful global software development. In Proceedings of the Evaluation and Assessment in Software Engineering (pp. 445-450).

Shafiq, M., Zhang, Q., Akbar, M. A., Khan, A. A., Hussain, S., Amin, F. E., ... \& Soofi, A. A. (2018). Effect of project management in requirements engineering and requirements change management processes for global software development. IEEE Access, 6, 25747-25763.

Thorburn, C., Gonulal, S. O., Remizoval, I. and Shindo, T. (2020).COVID-19 Outbreak: Insurance Implications and Responses. March 29, World Bank Group, Washington D.C. COVID-19-Outbreak-Global-Policy-Actions-onInsurance.pdf (worldbank.org)

W.H.O. (2020).Origin of SARS-COV-2.https://apps.who.int/iris/handle/10665/332197

W.H.O. (2021). COVID-19 Weekly Epidemiological Update. Geneva .May 9, 2021 https://www.who.int/publications/ $\mathrm{m} /$ item/covid-19-weekly-epidemiological-update

WHO-China Study (2021). WHO Convened Global Study of Origin of SARS-COV-2. Joint WHO-China Study Team Report, chinahttps://www.who.int/publications/m/item/who-convened-global-study-of-the-origins-of-sars-cov-2

World Bank Group (2020). COVID-19 Rapid Assessment: Impacts on the Nigerian Private Sectorsand Perspectives on Accelerating the Recovery. September 2020. International Finance Corporation (ifc), Washington D.C COVID19-Rapid-Assessment-Nigeria.pdf (ifc.org)

World Economic Forum (2020).Challenges and Opportunities in the Post-COVID-19 World. May 2020. World Economic Forum, Switzerland.

World Food Program (2021). COVID-19: Economic Impacts on Essential Needs for Urban and Slum Households in Nigeria. Urban Focus Nigeria: COVID-19 economic impacts on essential needs for urban and slum households in Nigeria (Published April 2021) Nigeria | ReliefWeb

Publisher's note: Science Impact Publishers remain neutral with regard to jurisdictional claims in published maps and institutional affiliations.

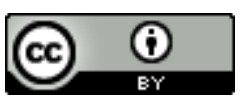

Open Access This article is licensed under a Creative Commons Attribution 4.0 International License, which permits use, sharing, adaptation, distribution and reproduction in any medium or format, as long as you give appropriate credit to the original author(s) and the source, provide a link to the Creative Commons license and indicate if changes were made. The images or other third-party material in this article are included in the article's Creative Commons license, unless indicated otherwise in a credit line to the material. If material is not included in the article's Creative Commons license and your intended use is not permitted by statutory regulation or exceeds the permitted use, you will need to obtain permission directly from the copyright holder. To view a copy of this license, visit https://creativecommons.org/licenses/by/4.0/.

(C) The Author(s) 2021 